\title{
Pemodelan Penjalaran Tsunami Akibat Erupsi Gunung Anak Krakatau Beserta Skenario Dike, Studi Kasus Teluk Jakarta
}

\author{
Nur Chasanah, Haryo Dwito Armono, Sujantoko, dan Juventus Welly Radianta Ginting \\ Departemen Teknik Perkapalan, Institut Teknologi Sepuluh Nopember (ITS) \\ e-mail: armono@oe.its.ac.id.
}

\begin{abstract}
Abstrak-Gunung Anak Krakatau merupakan gunung api aktif di Indonesia. Gunung Anak Krakatau terus memperlihatkan aktifitas vulkanik, hal ini dibuktikan oleh tsunami pada 22 Desember 2018 yang di akibatkan oleh erupsi Gunung Anak Krakatau. Jakarta sebagai ibukota negara dan memiliki jumlah penduduk terpadat di Indonesia sudah sewajarnya memiliki rencana mitigasi dini untuk mengurangi dampak dari bencana tsunami. Sejalan dengan usaha mitigasi tersebut, Pemda DKI Jakarta mengemukakan rencana tata ruang wilayah Jakarta tahun 2030 yang dikenal sebagai Master Plan NCICD (National Capital Integrated Coastal Development). Panduan Master Plan NCICD memiliki proyek utama dalam pengembangan pesisir Teluk Jakarta yaitu dengan pembangunan tanggul laut. Akan tetapi menurut penelitian sebelumnya, desain tanggul laut Master Plan NCICD yang berbentuk garuda dinilai kurang efektif dalam segi hydraulic. Penelitian ini bertujuan untuk memodelkan penjalaran tsunami yang disebabkan oleh erupsi Gunung Anak Krakatau ke Teluk Jakarta. Selain itu, penelitian dilanjutkan dengan memodelkan skenario jamak tsunami dike sebagai upaya dalam mereduksi ketinggian tsunami yang sampai ke Teluk Jakarta. Adapun kondisi awal kenaikan muka air laut merujuk pada tsunami akibat erupsi Gunung Krakatau tahun 1883. Pemodelan tsunami dilakukan dengan bantuan software MIKE 21. Hasil dari penelitian ini menunjukkan penjalaran tsunami selama 6 jam, dan diperoleh ketinggian elevasi muka air 1.437 meter pada titik validasi. Sedangkan tinggi elevasi muka air dari data validasi adalah $\mathbf{1 . 4 5 1}$ meter. Pemodelan dengan skenario dike dapat mengurangi tinggi elevasi muka air di dalam area dike masing - masing adalah $100 \%$ untuk skenario dike 1 (tipe dike tertutup), $99.58 \%$ untuk skenario dike 2 (tipe dike semi tertutup dengan 1 gap), 86.26\% untuk skenario dike 3 (tipe dike terbuka dengan 11 gap).
\end{abstract}

Kata Kunci-Gunung Anak Krakatau, NCICD Jakarta, Tanggul Laut, Tsunami, Tsunami Dike.

\section{PENDAHULUAN}

$\mathrm{B}$ ERADA dalam ring of fire menjadikan Negara Indonesia kaya akan gunung berapi, Indonesia memiliki gunung api terbanyak di dunia, yaitu 129 gunung aktif (15\% dari seluruh gunung api di dunia). Salah satu gunung api aktif di Indonesia adalah Gunung Anak Krakatau yang berlokasi di Selat Sunda, Lampung. Gunung Krakatau meletus dahsyat pada tahun 1883 , letusan tersebut menjadi letusan gunung api terdahsyat pada abad ke-19 setelah meletusnya Gunung Tambora pada tahun 1815. Letusan Gunung Krakatau 1883 menyebabkan tsunami besar yang menyapu hampir seluruh pantai di Lampung dan Banten. Gelombang tsunami diiringi oleh besarnya material magma dan batuan panas yang dimuntahkan oleh Krakatau telah

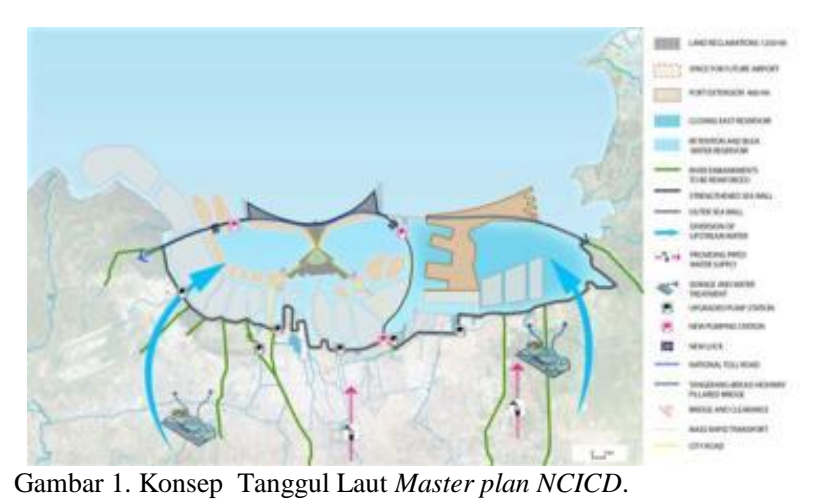

menewaskan sekitar 36.000 jiwa disertai dengan hancurnya berbagai pondasi penopang kehidupan masyarakat [1].

Menurut Verbeek dalam jurnal yang ditulis oleh Sutawidjaja (2006), penelitian mengenai tsunami yang diakibatkan letusan Gunung Krakatau tahun 1883 di simulasikan dengan inisiasi awal pembangkitan gelombang dengan ledakan phreatomagmatik. Ketika hasil simulasi di analisis, terlihat gelombang tsunami mengalami penjalaran dan bertransfromasi ke segala arah. Gelombang tsunami menyebar ke arah selatan menuju Samudera Hindia dan sebagian gelombang terdifraksi ke arah onshore. Gelombang tsunami juga menyebar ke arah utara, bepropagasi ke arah Laut Jawa, dan sebagian gelombang mengalami pembelokan hingga ke Teluk Jakarta. Gelombang tsunami yang sampai ke Teluk Jakarta mengalami deformasi gelombang, sehingga menurut hasil simulasi tinggi gelombang maksimum yang sampai di Teluk Jakarta adalah $3.8 \mathrm{~m}$ dan tinggi gelombang minimum adalah $0.4 \mathrm{~m}$.

Jakarta adalah ibukota negara Indonesia yang menjadi pusat segela pengembangan infrastruktur yang mendukung perekonomian Indonesia. Namun, sebagai salah satu kota penting di Indonesia, Jakarta memiliki permasalahan pengelolaan wilayah pesisir yang kompleks. Permasalahan pesisir Jakarta telah mengarah pada degradasi lingkungan yang memiliki pengaruh negatif, diantara meningkatnya banjir rob, menurunnya ketersediaan air bersih, menurunnya kualitas dan kuantitas hasil perikanan serta dampak negatif lainnya. Pemda DKI Jakarta melalui Perda No.1 Tahun 2012 mengenai Rencana Tata Ruang Wilayah DKI 2030 mengemukakan satu program utama yang dikenal sebagai rencana pembangunan tanggul laut. Rencana ini juga dikenal sebagai Master Plan NCICD (National Capital Integrated Coastal Development). Panduan Master Plan NCICD memiliki proyek utama dalam pengembangan pesisir Jakarta yaitu dengan pembangunan tanggul laut. 


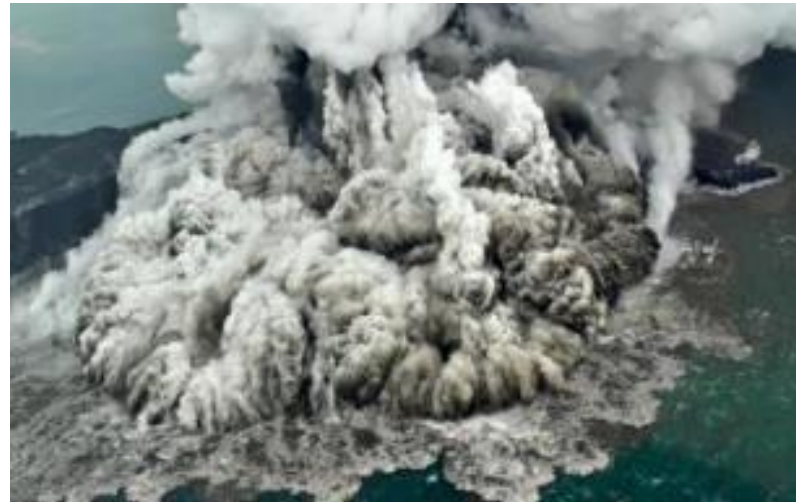

Gambar 2. Jatuhnya Material Erupsi.

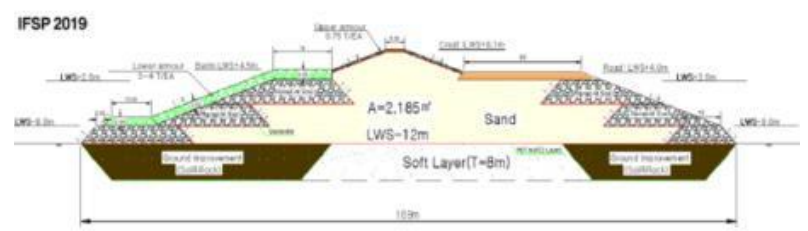

Gambar 3. Layout tampat samping tsunami dike

Konsep tanggul laut yang dicanangkan dalam Master Plan NCICD sejalan dengan usaha mitigasi bencana untuk meminimalisir kemungkinan gelombang tsunami akibat erupsi Gunung Anak Krakatau. Design tanggul laut yang akan di bangun di lepas laut di Teluk Jakarta diusung dengan konsep Garuda. Konsep ini disebut sebagai lambang negara, kepala garuda menghadap ke arah utara dan sayap melintang ke arah barat dan timur. Bachtiar dkk (2017) telah menguji coba design tanggul laut tersebut dari segi hydraulic. Menurut penelitiannya, layout tanggul berbentuk garuda tersebut kurang optimum dalam mereduksi tinggi gelombang tsunami yang menjalar ke Teluk Jakarta. Hasil simulasi menunjukkan tinggi gelombang maksimum terdeformasi ke arah kepala garuda yang berbentuk cekung hingga mencapai elevasi maksimum $11 \mathrm{~m}$ dan elevasi minimum $6 \mathrm{~m}$.

Berdasarkan latar belakang tersebut, dalam penelitian ini kami memodelkan penjalaran gelombang tsunami akibat erupsi Gunung Anak Krakatau dengan bantuan perangkat lunak MIKE 21. Dari hasil analisa ini diharapkan dapat menunjukkan tinggi gelombang tsunami pertama yang mencapai Teluk Jakarta dan waktu penjalaran dari Selat Sunda ke Teluk Jakarta. Pemodelan dilakukan melalui simulasi numerik yang bersumber dari initial condition Tsunami Krakatau 1883. Simulasi dilanjutkan dengan pemodelan tanggul laut yang berfungsi sebagai tsunami dike sebagai upaya mitigasi bencana yang sejalan dengan program NCICD yang dicanangkan pemerintah.

\section{METODOLOGI PENELITIAN}

Simulasi model digunakan dengan mengaplikasikan metode nested, dimana hasil simulasi model detail disimulasikan dari hasil simulasi model global. Data yang dimasukkan ke dalam model detail berupa kenaikan muka air hasil simulasi model global. Model global mencakup Selat Sunda dan Teluk Jakarta, sedangkan model detail berupa model dengan cakupan area Teluk Jakarta. Model dibangun dengan konfigurasi unstructure-grid dimana domain model mengikuti profil garis pantai yang kompleks dengan resolusi grid kasar ke arah lepas pantai dan lebih

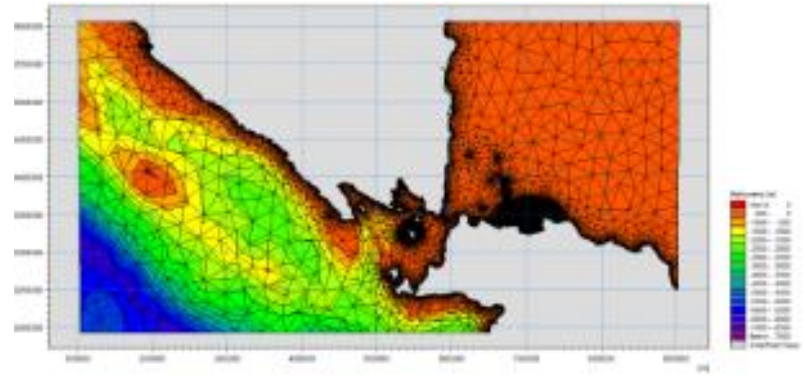

Gambar 4. Domain Model Global.

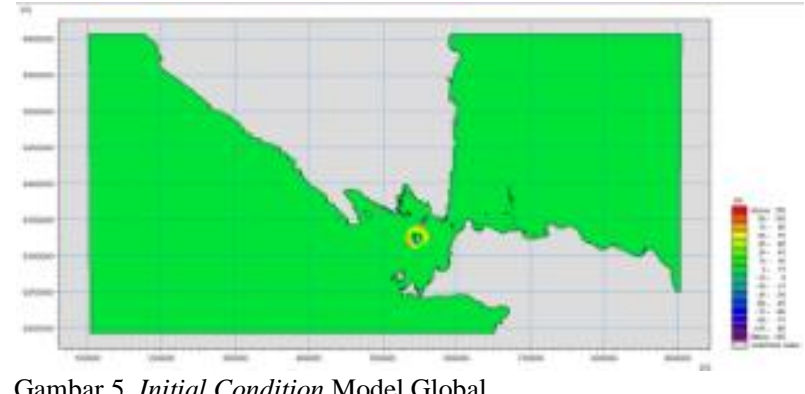

Gambar 5. Initial Condition Model Global

detail ke arah pantai. Hal ini berfungsi untuk mengefektifkan waktu komputasi.

\section{A. Tinjauan Pustaka}

Gunung Anak Krakatau (286.63 m dpl) adalah gunung berapi strato tipe A, Gunung Krakatau merupakan salah satu dari empat gugusan pulau yang terletak di Selat Sunda. Berdasarkan hasil pengukuran topografi [2], selama 21 tahun Gunung Krakatau mengalami penambahan luas daratan dan ketinggian. Pada 1983 luasnya adalah 156,75 ha dengan ketinggian 201,5 m dpl maka pada tahun 2004 berturut - turut adalah 212,5 ha dan 286,63 m dpl.

Sutawidjaja (2006) dalam penelitiannya menyebutkan bahwa pada tahun 2040 kemungkinan akan terjadi kembali letusan dahsyat yang disamakan dengan letusan Gunung Krakatau 1883. Pernyataan tersebut didasarkan pada analisis batuan lava yang menghasilkan komposisi silika yang terus meningkat setiap waktu. Lelehan lava tersebut memasuki persentase silika 54.77\% terhitung pada bulan Juli 1996. Apabila peningkatan persentase silika terjadi secara konsisten dan diasumsikan meningkat satu persen dalam sepuluh tahun, maka untuk mencapai persentase silica $68 \%$ (besarnya persen silika ketika terjadi letusan Gunung Krakatau 1883) dibutuhkan waktu 140 tahun.

Menurut Sutawidjaja (2006) pada 27 Agustus 1883 Gunung Krakatau mengalami erupsi dan kejadian ini dianggap sebagai kejadian terbesar dalam sejarah meletusnya Gunung Krakatau. Lontaran material vulkanik dengan volume $18 \mathrm{~km}^{3}$, dan tinggi kolom letusan $80 \mathrm{~km}$ telah menimbulkan tsunami setinggi 30 meter di sepanjang pantai barat Banten dan pantai selatan Lampung. Stehn (1939) berpendapat bahwa pembentukan kaldera terjadi akibat runtuhan gunung api atau longsoran di dasar laut oleh pengosongan magma dan gas yang tererupsi. Runtuhan ini menekan air laut sehingga menyebabkan terjadinya tsunami yang menyapu pantai barat Jawa dan pantai selatan Sumatera. Pendapat kedua oleh Yokoyama (1981) yang menyebutkan tsunami terjadi setelah adanya pelepasan energi yang sangat besar. Ia melakukan survei gravimetri di kawasan Krakatau, dan berkeyakinan bahwa tsunami terjadi akibat erupsi material $18 \mathrm{~km}^{3}$ yang menekan air laut. 

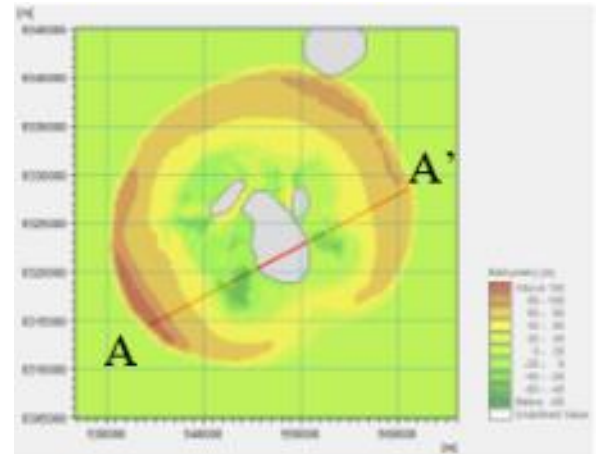

Gambar 6. Garis Potong Initial Condition.

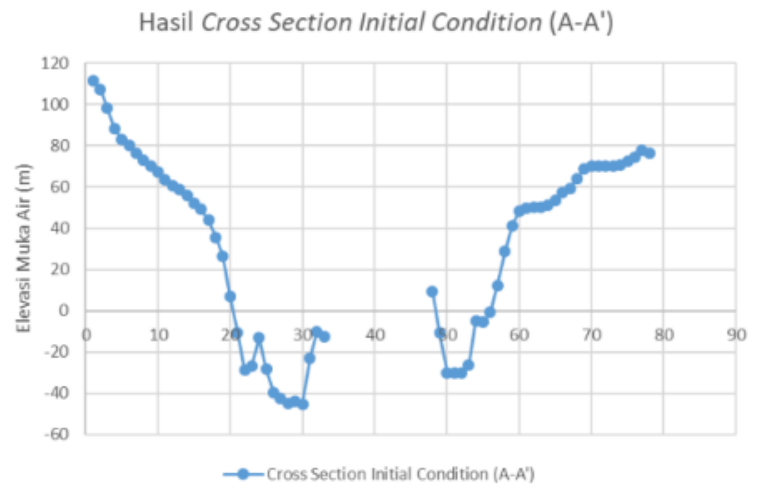

Gambar 7. Grafik Cross Section Initial Condition (A-A')
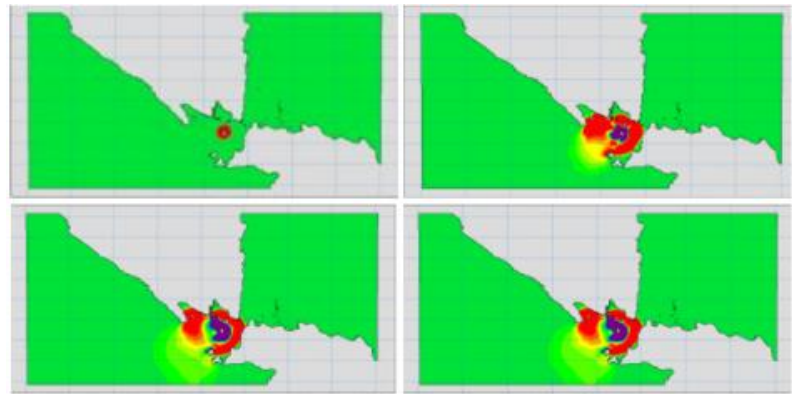

Gambar 8. 50 Step Pertama dari 864 Step Hasil Running Penjalaran Gelombang 2 Dimensi.
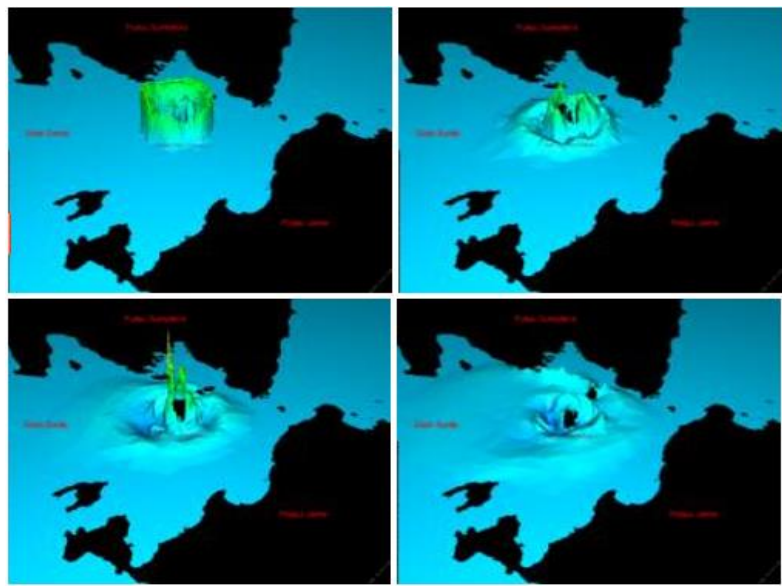

Gambar 9. 50 Step Pertama dari 864 Step Hasil Running Penjalaran Gelombang 3 Dimensi.

Menurut Imamura dkk (2011) tsunami hasil erupsi Gunung Krakatau pada tahun 1883 disebabkan oleh tiga sebab yaitu runtuhnya kaldera, letusan phreatomagmatic, dan aliran piroklastik. Dari ketiga sebab itu, dilakukan analisa numerik untuk mengetahui penyebab yang paling mungkin untuk membangkitkan tsunami. Dari hasil penelitian, disimpulkan bahwa aliran piroklastik adalah
Tabel 1.

Validasi Elevasi Muka Air

\begin{tabular}{|c|c|c|}
\hline $\begin{array}{c}\text { Tinggi Elevasi Muka } \\
\text { Air Validasi }\end{array}$ & \multicolumn{2}{|c|}{ Tinggi Elevasi Muka Air Pemodelan } \\
\hline \multirow{6}{*}{$1.45 \mathrm{~m}$} & Manning Number 20 & $0.89030 \mathrm{~m}$ \\
\hline & Manning Number 24 & $1.0927 \mathrm{~m}$ \\
\hline & Manning Number 28 & $1.27688 \mathrm{~m}$ \\
\hline & Manning Number 31 & $1.40111 \mathrm{~m}$ \\
\hline & Manning Number 32 & $1.44041 \mathrm{~m}$ \\
\hline & Manning Number 33 & $1.47818 \mathrm{~m}$ \\
\hline \multicolumn{3}{|c|}{$\begin{array}{c}\text { Tabel } 2 . \\
\text { Koreksi } M A P E\end{array}$} \\
\hline$M A P E$ & \multicolumn{2}{|l|}{ Interpretasi } \\
\hline$<10 \%$ & \multicolumn{2}{|l|}{ Sangat Baik } \\
\hline $10 \%-20 \%$ & \multicolumn{2}{|l|}{ Baik } \\
\hline $20 \%-50 \%$ & \multicolumn{2}{|l|}{ Cukup } \\
\hline$>50 \%$ & \multicolumn{2}{|l|}{ Buruk } \\
\hline
\end{tabular}

Tabel 3.

Validasi Nilai Eddy Viscosity

\begin{tabular}{cc}
\hline \hline Nilai Eddy Viscosity & Hasil Koreksi \\
\hline 0.27 & $14.3451 \%$ \\
0.28 & $14.3419 \%$ \\
0.29 & $14.3373 \%$ \\
0.3 & $14.3336 \%$ \\
\hline
\end{tabular}

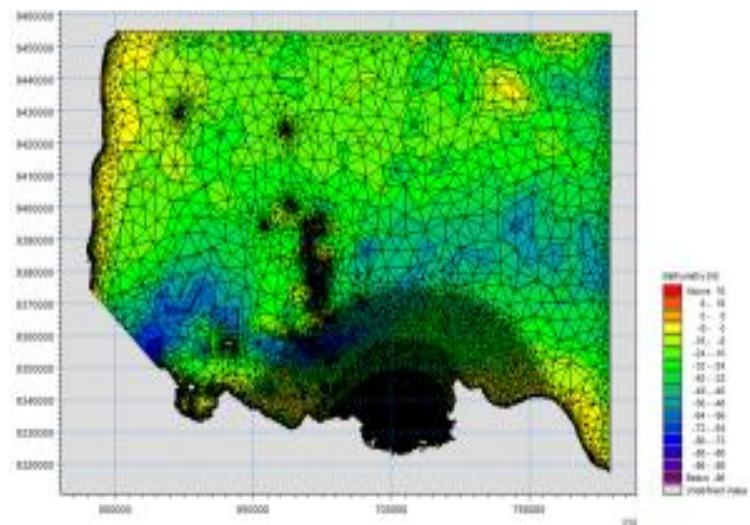

Gambar 10. Domain Model Detail.

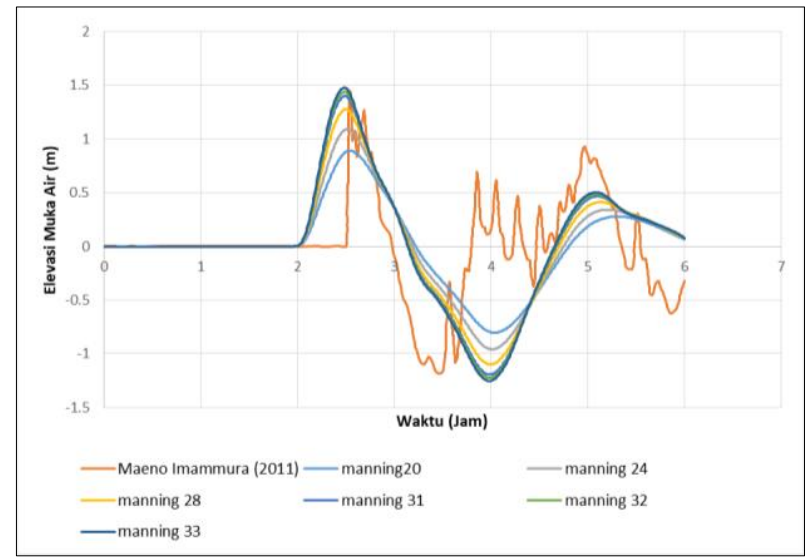

Gambar 11. Grafik Validasi Model Globa

penyebab yang paling mungkin. Aliran piroklastik ini disimulasikan dengan aliran bervolume $>5 \mathrm{~km}^{3}$ dan debit rata - rata $107 \mathrm{~m}^{3} / \mathrm{s}$ yang dialirkan ke air. Penelitian ini membuktikan tinggi tsunami yang dimodelkan hampir sama dengan rekaman pasang surut di Batavia (Jakarta) yaitu 1.4 $\mathrm{m}$ dengan periode 2 jam. 


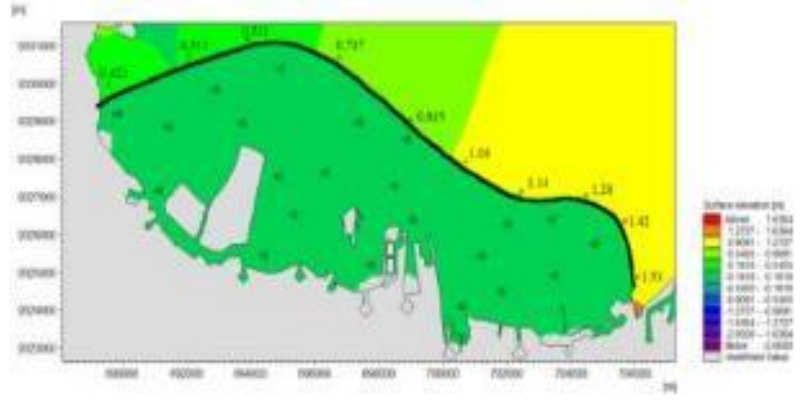

Gambar 12. Persebaran Elevasi Muka Air pada Dike 1.

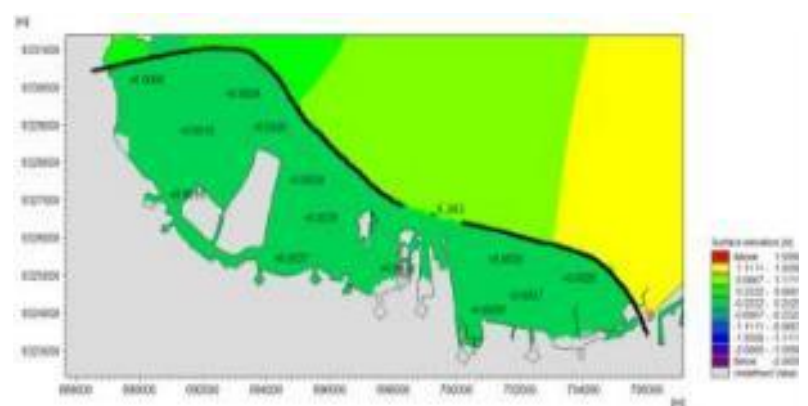

Gambar 13. Persebaran Elevasi Muka Air pada Dike 2.

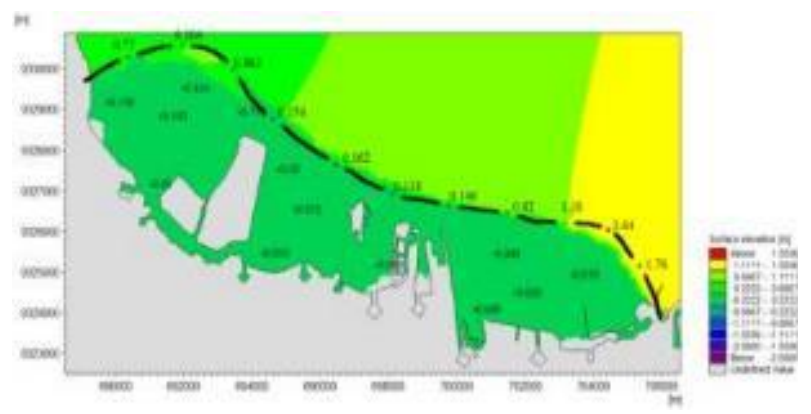

Gambar 14. Persebaran Elevasi Muka Air pada Dike 3

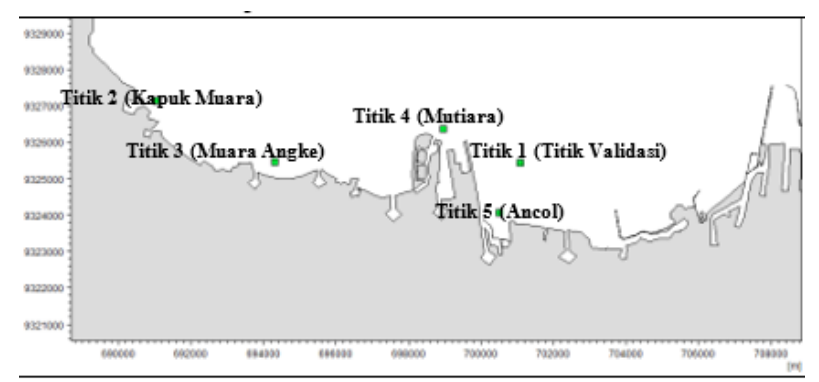

Gambar 15. Lokasi Titik Tinjau.

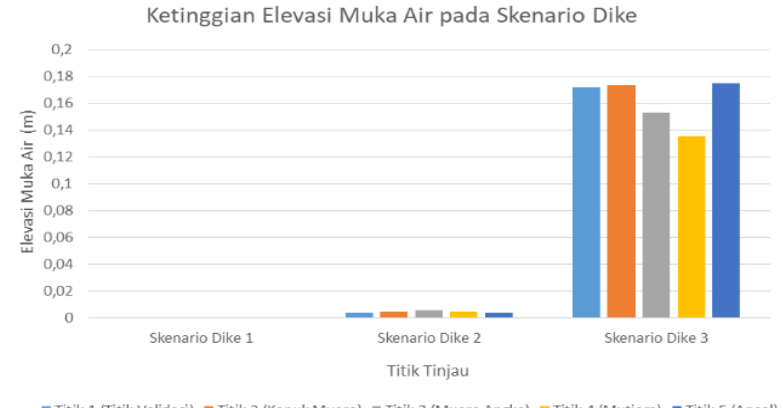

Gambar 16. Perbandingan Elevasi Setiap Skenario.

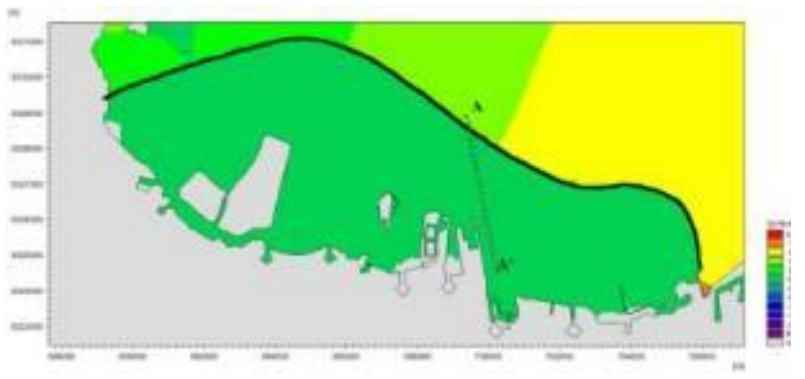

Gambar 17. Cross Section A-A'

Tabel 4.

Persentase Penuruanan Elevasi Muka Air

\begin{tabular}{ll}
\hline \hline Skenario Dike & Tipe Tanggul $\quad$ Persentase rata-rata penurunan elevasi muka air \\
\hline Skenario Dike 1 & Tertutup \\
Skenario Dike 2 & Semi Terbuka dengan 1 gap \\
Skenario Dike 3 & Terbuka dengan 11 gap \\
\hline \hline
\end{tabular}

Tsunami merupakan serangkaian gelombang air pasang yang bergerak secara cepat ke arah daratan. Tsunami dapat disebabkan oleh gempa bumi atau letusan gunung api laut [3]. Menurut Imamura (1994) gerak gelombang tsunami diekspresikan dengan teori gelombang perairan dangkal. Teori gelombang panjang yang didekati dengan teori pendekatan yang berlaku untuk gelombang dengan kedalaman relatif kecil yang mana percepatan vertikal dari air dapat diabaikan dengan percepatan gravitasi. Berikut persamaan perairan dangkal yang digunakan dalam perangkat lunak MIKE 21 Flow Model FM modul HD [4].

$\frac{\partial u}{\partial x}+\frac{\partial v}{\partial y}+v \frac{\partial w}{\partial z}$

Persamaan momentum dalam arah $\mathrm{x}$ :

$$
\begin{aligned}
& \frac{\partial u}{\partial t}+\frac{\partial u^{2}}{\partial x}+\frac{\partial v u}{\partial y}+\frac{\partial w u}{\partial z}=f v-g \frac{\partial \eta}{\partial x}-\frac{1}{\rho_{0}} \frac{P_{a}}{\partial x}-\frac{g}{\rho_{0}} \int_{z}^{\eta} \frac{\partial \rho}{\partial x} d z+ \\
& F_{u}+\frac{\partial}{\partial z}\left(V_{t} \frac{\partial u}{\partial z}\right) u_{s} S
\end{aligned}
$$

Persamaan momentum dalam arah y: $\frac{\partial u}{\partial t}+\frac{\partial v^{2}}{\partial y}+\frac{\partial u v}{\partial x}+\frac{\partial w v}{\partial z}=f u-g \frac{\partial \eta}{\partial y}-\frac{1}{\rho_{0}} \frac{P_{a}}{\partial y}-\frac{g}{\rho_{0}} \int_{z}^{\eta} \frac{\partial \rho}{\partial y} d z+$

$F_{v}+\frac{\partial}{\partial z}\left(V_{t} \frac{\partial v}{\partial z}\right) v_{s} S$

Dimana :

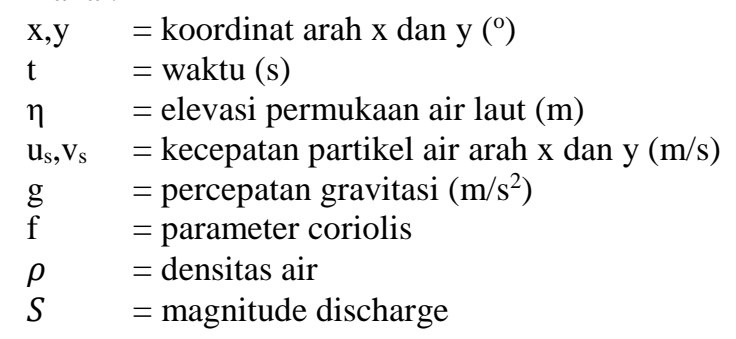

\section{B. Pengumpulan Data}

\section{1) Batimetri}

Data batimetri untuk sebagian besar area pemodelan bersumber dari GEBCO dan untuk area - area fokusan kajian seperti area Gunung Anak Krakatau dan area Teluk Jakarta didapatkan dari digitasi manual. 


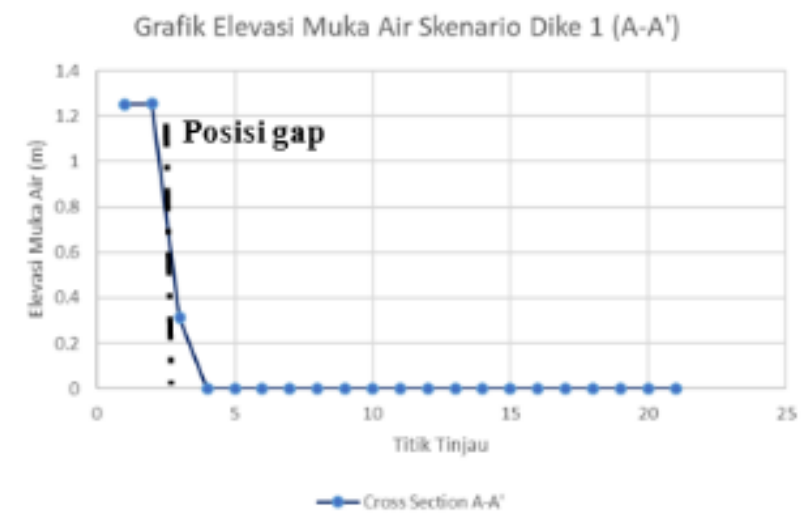

Gambar 18. Hasil Cross Section A-A'.

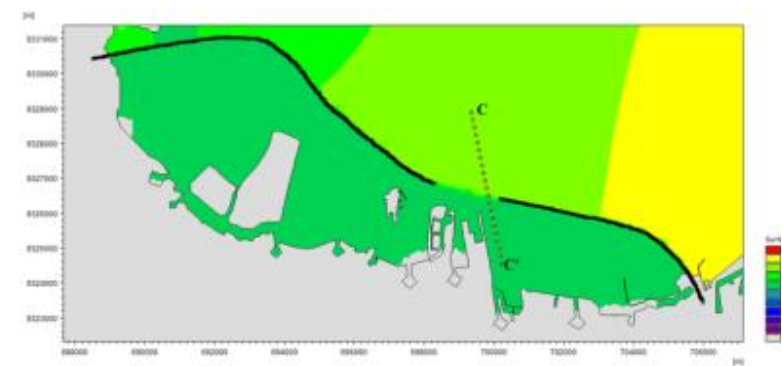

Gambar 19. Cross Section C-C'

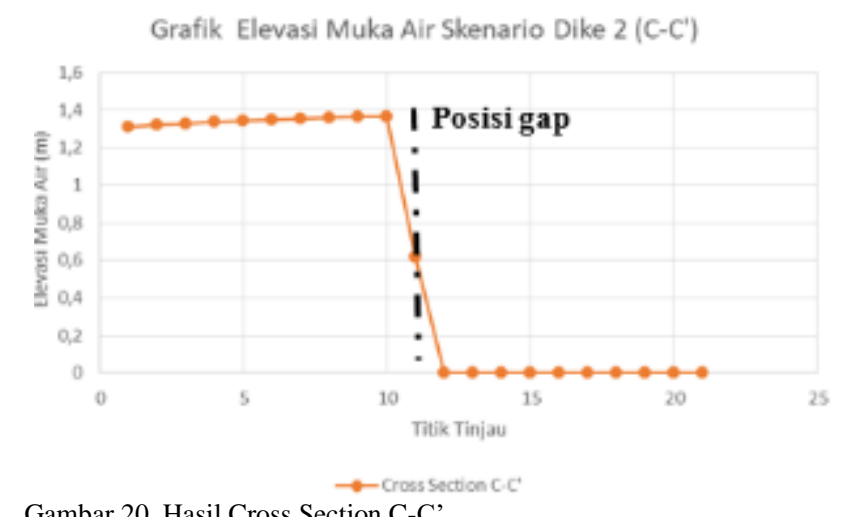

Gambar 20. Hasil Cross Section C-C'

\section{2) Kenaikan Muka Air}

Pembangkitan tsunami akibat erupsi Gunung Krakatau diakibatkan oleh tumpahan material erupsi Gunung Krakatau ke perairan. Menurut penelitian Maeno, dkk (2011) menyimpulkan aliran piroklastik (jatuhnya material ke air) adalah mekanisme paling memungkinkan untuk pembangkitan tsunami krakatau 1883. Aliran piroklastik dengan volume $18 \mathrm{~km}^{3}$ dan tinggi kolom $80 \mathrm{~km}$ memasuki air dan mampu membangkitkan air pasang tsunami.

\section{3) Shoreline}

Data shoreline atau garis pantai berupa garis pantai bagian selatan pulau sumatra dan bagian barat pulau jawa. Data shoreline ditambah dengan pulau - pulau yang berada dilokasi tersebut dan data shoreline pulau reklamasi. Data shoreline diperoleh dari hasil digit manual dengan sumber google earth. Data shoreline berbentuk format (*.xyz).

\section{4) Tsunami Dike}

Design tsunami dike diperoleh dari Balai Pengembangan dan Penelitian Pantai. Layout tampak samping yang dari dike dapat dilihat pada Gambar 3.

Desain ketinggian struktur tsunami dike yang dimodelkan memiliki beberapa parameter yang mempengaruhi. Diantaranya adalah tidal level, wave run-up height, settlement yang terdiri dari land subsidence dan

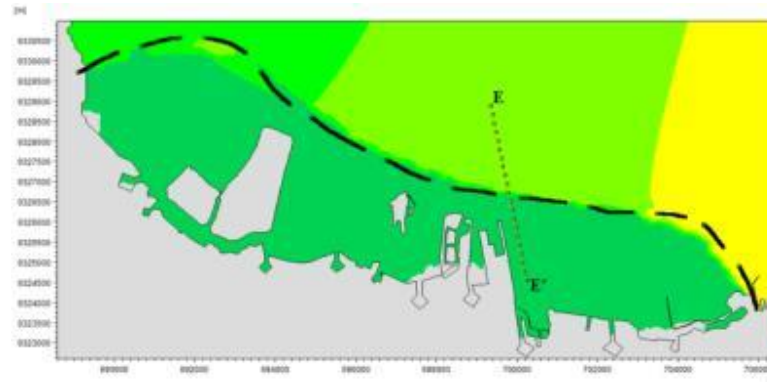

Gambar 21. Cross Section E-E'

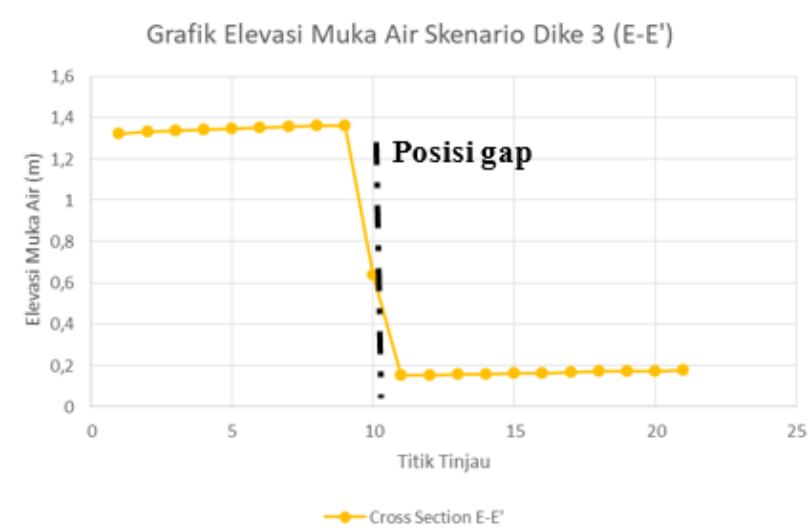

Gambar 22. Hasil Cross Section E-E'.

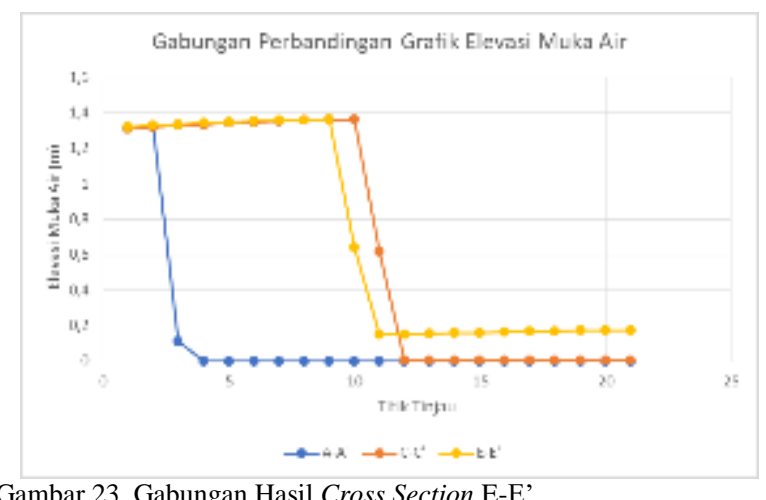

consolidation, freeboard, dan crest level. Data wave runup dibagi menjadi empat bagian. Bagian wave run - up tertinggi menunjukkan angka 9.1 meter sedangkan wave run - up terendah adalah 7 meter.

Pada penelitian ini, Pre-design yang dimodelkan hanya tampak atas saja dan memiliki 5 tipe tsunami dike, karena keterbatasan ruang pada jurnal ini ada 3 dike yang akan dibahas:

\section{Skenario 1}

- Base Case

- Tipe tanggul tertutup

- Tinggi tanggul sesuai design dike height

- Lebar tanggul $6 \mathrm{~m}$

2. Skenario 2

- Tipe tanggul semi tertutup

- Memiliki satu pintu untuk jalur pelayaran

- Kondisi tanggul existing

- Tinggi tanggul sesuai design dike height

- Lebar tanggul $6 \mathrm{~m}$

3. Skenario 3

- Tipe tanggul open dike

- Tanggul memiliki banyak gap

- Tinggi tanggul sesuai design dike height

- Lebar tanggul 6 m 


\section{5) Validasi}

Data validasi berasal dari jurnal yang berjudul "Tsunami Generation by a rapid entrace of pyroclastic flow in to the sea during the 1883 Krakatau Eruption, Indonesia". Validasi dilakukan dengan membandingkan elevasi muka air dari jurnal dengan elevasi muka air hasil simulasi pemodelan (hasil output software MIKE 21).

\section{HASIL DAN PEMBAHASAN}

\section{A. Daerah Penelitian}

Daerah penelitian berlokasi di Teluk Jakarta, perairan yang terletak di sebelah utara Jakarta. Teluk Jakarta secara geografis terletak diantara Tanjung Karawang disebelah timur dan Tanjung Pasir disebelah barat, dan secara administratif terletak di tiga provinsi yaitu Provinsi Banten, DKI, dan Provinsi Jawa Barat. Perairan Teluk Jakarta merupakan perairan dangkal semi tertutup dengan kedalaman rata - rata 15 meter dengan luas $514 \mathrm{~km}^{2}$. Perairan Teluk Jakarta memberikan banyak jasa ekologis seperti pelayaran, pelabuhan, turime, dan perikanan. Fokusan daerah penelitian kedua adalah Gunung Anak Krakatau. Gunung Anak Krakatau terletak di Selat Sunda, termasuk ke dalam wilayah Lampung Selatan. Gunung Anak Krakatau adalah salah satu gunung api aktif dari 129 gunung api di Indonesia, yang berderet sepanjang $7000 \mathrm{~km}$ mulai ujung utara Sumatera, Jawa, Nusa Tenggara, Maluku sampai ke Sulawesi Utara.

\section{B. Pemodelan Global}

Secara garis besar pemodelan global dengan menggunakan program MIKE 21 pada tugas akhir ini dibagi menjadi tiga tahapan. Tahapan tersebut antara lain adalah meshing dengan menggunakan mesh generator (*.mdf), pembuatan file (*.dfsu) sebagai input elevasi muka air, dan simulasi hidrodinamika dalam modul HD. Dalam pemodelan ini datum yang digunakan adalah UTM (Universal Transverse Mercator).

\section{1) Meshing Pemodelan Global}

Meshing pada pemodelan ini berdasarkan flexible mesh dengan menggunakan mesh generator dari MIKE 21. Tahapan dalam meshing yang pertama kali dilakukan adalah mengimpor data shoreline ke dalam mesh generator. Pembuatan mesh pada pemodelan global ini ditentukan oleh beberapa parameter yakni luas elemen mesh maksimum 500 x $106 \mathrm{~m}^{2}$, sudut mesh minimum sebesar 26 derajat, serta jumlah titik maksimum $100 \times 10^{3}$, smoothing dan jumlah iterasi 10 kali.

2) Domain Model Global

Setelah meshing berhasil dilakukan pemodelan berlanjut dengan membuat file berekstensi (*.mesh) yang akan digunakan sebagai domain model global. File domain merupakan hasil dari interpolasi mesh terhadap nilai batimetri.

\section{3) Initial Condition}

Pembuatan initial condition memiliki tahapan yang sama seperti pembuatan domain. File initial condition merupakan hasil interpolasi mesh terhadap nilai digitasi kenaikan muka air akibat erupsi Gunung Anak Krakatau.

Untuk lebih menunjukkan kenaikkan muka air laut dengan lebih jelas, dapat dilihat dari hasil cross section AA'.

Hasil dari cross section (A-A') pada Gambar 6. initial condition di tunjukkan oleh grafik pada Gambar 7. Pada bagian tengah grafik terdapat gap (nilai yang tidak terisi) yang menunjukkan bahwa bagian tersebut adalah daratan atau area Gunung Anak Krakatau.

\section{Running Model Global}

Running model dilakukan pada modul hydrodynamic Flow Model FM MIKE 21. Dalam simulasi ini waktu yang digunakan adalah 6 jam dengan time step interval 5 detik dan jumlah time step sebanyak 864. Untuk proses kalibrasi pada pemodelan global, parameter bed resistance dan eddy viscosity di input dengan beberapa nilai yang berbeda.

Model global di running dengan 6 nilai manning number yang berbeda, dengan 1 nilai eddy viscosity yang sama. Setelah menemukan nilai manning number yang memiliki nilai koreksi paling kecil terhadap data validasi, nilai manning number tersebut akan di running kembali dengan 5 nilai eddy viscosity yang berbeda untuk mencari nilai koreksi yang lebih mendekati data validasi.

\section{Hasil Simulasi 2 Dimensi Model Global}

Setelah running berhasil dilakukan, hasil running akan mengeluarkan output berupa penjalaran tsunami. Output penjalaran tsunami tersimpan dalam file berfomat '.dfsu' dengan jumlah 864 time step. Gambar 8 adalah dokumentasi 50 step pertama hasil penjalaran gelombang.

\section{E. Validasi Model Global}

Validasi dilakukan dengan mengekstrak grafik gelombang pada titik tinjau di Teluk Jakarta. Grafik ini diperoleh dari file (*.dfsu) yang mana file ini merupakan salah satu output dari running model. Dalam koordinat UTM titik tinjau memiliki nilai Easting 701091.346171 dan Northing 9325432.752811. Titik ini berdekatan dengan Pelabuhan Mutiara.

Gambar 11 merupakan perbandingan grafik hasil running dengan nilai manning number yang berbeda, gabungan grafik tersebut di plot bersama dengan grafik validasi.

Evaluasi hasil simulasi dilakukan dengan perbandingan ketinggian gelombang hasil simulasi dengan gelombang validasi. Ketinggian yang hampir sama dengan gelombang validasi adalah hasil yang akan di kalibrasi ulang bersama dengan koefisien eddy viscosity. Dengan menggunakan evaluasi dengan perbandingan ketinggian gelombang, diantara 5 nilai manning number yang telah dimodelkan memiliki koreksi paling baik sebesar dengan manning number $32 \mathrm{~m}^{(1 / 3)} / \mathrm{s}$. Perbandingan tinggi gelombang dapat dilihat pada Tabel 1 .

Manning number $32 \mathrm{~m}^{(1 / 3)} / \mathrm{s}$ kemudian di setting kembali dengan 5 eddy viscosity. Evaluasi hasil simulasi dilakukan dengan perhitungan presentase rata - rata kesalahan absolut atau Mean Absolute Percentage Error (MAPE). Menurut Heizer dan Render (2015) dalam penelitian Haviz (2019) disebutkan MAPE didapat dari selisih absolut antara data pengukuran dan data hasil simulasi dibanding dengan data pengukuran, dikali seratus persen. Persamaan dari kriteria MAPE adalah sebagai berikut :

$M A P E=\frac{1}{n} \sum\left(\frac{\left|h_{o}-h_{1}\right|}{h_{o}}\right) \times 100 \%$

Dimana,

ho= Data Pembanding

h1 $=$ Data Hasil Simulasi

$\mathrm{n}=$ Jumlah Data

Hasil koreksi setiap nilai eddy viscosity yang telah selesai di running dapat dilihat pada Tabel 3. 
Dari Tabel 3 dapat dilihat bahwa hasil koreksi dari nilai eddy viscosity 0.3 adalah yang terkecil, yaitu sebesar $14.3336 \%$.

\section{F. Pemodelan Detail}

Pembuatan pada model detail memiliki langkah - langkah yang sama dengan pembuatan model global. Pembuatan model detail ini bertujuan untuk lebih mendetailkan proses komputasi dengan memperkecil luas area meshing.

\section{1) Meshing Pemodelan Detail}

Parameter pembuatan mesh pada pemodelan detail terdiri dari luas elemen mesh maksimum 26 x $106 \mathrm{~m}^{2}$, sudut mesh minimum sebesar 26 derajat, serta jumlah titik maksimum $100 \times 10^{3}$, smoothing dan jumlah iterasi 10 kali.

Untuk mengefektifkan waktu komputasi, mesh dibuat teliti pada fokusan daerah penelitian saja yaitu daerah Teluk Jakarta. Cara yang digunakan adalah membuat arc sebagai batasan mesh yang ingin di detailkan. Batasan mesh di Teluk Jakarta dibagi menjadi 3 bagian mesh dengan maximum area $10.000 \mathrm{~m}^{2}, 30.000 \mathrm{~m}^{2}, 70.000 \mathrm{~m}^{2}, 300.000$ $\mathrm{m}^{2}, 700.000 \mathrm{~m}^{2}$.

\section{2) Domain Model Detail}

Untuk membuat domain dibutuhkan interpolate mesh dengan kombinasi batimetri. Setelah file selesai diinterpolate, file di export menjadi domain dengan format file (*.mesh).

\section{3) Initial Condition Model Detail}

Initial condition pada model detail tidak perlu dibuat lagi. Initial condition pada model detail dikondisikan dengan memakai initial condition pada model global. Adapun cara melakukannya adalah dengan meng-extract file initial condition pada model besar kemudian file tersebut dikeluarkan pada salah satu boundary condition pada model detail. Dalam pemodelan ini, initial condition akan dikelarkan pada boundary condition yang berbatasan dengan Selat Sunda. File initial condtion memiliki format (*.dfs1)

\section{G. Running Pemodelan Tsunami Dike}

Untuk melakukan running pada pemodelan detail dibutuhkan file dengan format (*.mesh), (*.dfsu), dan file digitasi tsunami dike. File dengan format (*.mesh) dibuat dengan area yang lebih kecil yaitu meliputi wilayah Teluk Jakarta dan perairan diatasnya. Hal ini bertujuan agar meshing yang dilakukan bisa lebih detail dan akurat. File dengan format (*.dfsu) diambil dari initial condition model global yang kemudian dikeluarkan pada salah satu boundary condition pada model detail. Kemudian untuk file digitasi tsunami dike merupakan file berformat (*.xyz) yang merepresentasikan tipe skenario dike.

\section{H. Persebaran Elevasi Muka Air dalam Skenario Dike}

Peta persebaran elevasi muka air ini menunjukkan hasil ekstrak data simulasi pemodelan detail dengan adanya pengaruh skenario dike 1 . Skenario dike 1 merupakan tipe tanggul tertutup yang tidak memiliki gap. Tanggul di pasang menutupi bagian barat Teluk Jakarta. Tanggul tersebut memiliki panjang $20 \mathrm{~km}$ yang membentang dari Pantai Ancol (batas timur) sampai Pelabuhan Angke (batas barat). Dengan adanya skenario dike 1 yang di pasang mengakibatkan penjalaran gelombang tsunami tidak dapat masuk ke dalam area dalam tanggul. Hal ini menyebabkan ketinggian elevasi di dalam area tanggul adalah $0 \mathrm{~m}$. Peta persebaran elevasi muka air yang di tampilkan adalah elevasi muka air pada time step ke 360 dari total 864 time step. Gambar 12 adalah peta persebaran elevasi muka air pada skenario dike 1 .

Skenario dike 2 merupakan tipe tanggul semi terbuka dan memiliki satu gap. Gap ini berfungsi sebagai jalur pelayaran dan satu - satunya pintu keluar masuk air. Skenario dike 2 memiliki total panjang tanggul sebesar $19 \mathrm{~km}$ dan panjang gap pada tanggul sebasar 1900 meter. Elevasi muka air penjalaran tsunami berhasil di reduksi dengan adaanya tanggul, sehingga ketinggian elevasi muka air di dalam area dike mengalami penurunan. Peta persebaran elevasi muka air yang di tampilkan adalah elevasi muka air pada time step ke 360 dari total 864 time step. Gambar 13 adalah peta persebaran elevasi muka air pada skenario dike 2 .

Skenario dike 3 merupakan tipe tanggul terbuka dan yang paling banyak memiliki gap, yaitu 11 gap. Gap ini berfungsi sebagai jalur pelayaran dan pintu keluar masuk air. Skenario dike 2 memiliki total panjang tanggul sebesar $19 \mathrm{~km}$ dan panjang gap masing - masing sebesar $600 \mathrm{~m}$. Elevasi muka air penjalaran tsunami berhasil di reduksi dengan adanya tanggul, sehingga ketinggian elevasi muka air di dalam area dike mengalami penurunan. Peta persebaran elevasi muka air yang di tampilkan adalah elevasi muka air pada time step ke 360 dari total 864 time step. Gambar 14 adalah peta persebaran elevasi muka air pada skenario dike 3 .

\section{Perbandingan Tinggi Elevasi Muka Air}

Dari hasil persebaran tinggi elevasi muka air pada masing - masing dike, analisis dilanjutkan dengan membandingkan elevasi muka air pada 3 skenario dike. Analisis ini bertujuan untuk melihat keefektifan tanggul dalam meredam tsunami. Untuk analisis, diambil titik tinjau yang kemudian dilakukan ekstrak dan pengolahan data pada titik tersebut. Hasil dari pengolahan data pada titik tinjau adalah elevasi muka air maksimum. Elevasi muka air maksimum nantinya akan dibandingkan antar skenario dike. Titik tinjau yang akan dianalisis berjumlah lima titik. Titik - titik tersebut merupakan titik yang berdekatan dengan lokasi - lokasi strategis di Teluk Jakarta, seperti halnya Pelabuhan dan kawasan pariwisata. Gambar 15 menunjukkan lokasi dari titik tinjau.

Setelah menentukan titik tinjau, maka data hasil running pemodelan detail dapat di ekstrak sesuai koordinat UTM dari titik tinjau yang telah di tentukan. Hasil ekstrak data yang berupa ketinggian elevasi maksimum tiap skenario dike dapat dilihat pada Gambar 16.

Pada skenario dike 1 semua titik tinjau memiliki elevasi maksimum $0 \mathrm{~cm}$, hal ini disebabkan oleh tipe skenario dike 1 adalah tipe tertutup, sehingga air tidak dapat melewati dike. Skenario dike 3 memiliki rata - rata tinggi elevasi muka air yang paling tinggi diantara skenario dike lain, hal ini disebabkan banyaknya gap yang ada pada skenario dike 3 sehingga air dapat mudah masuk ke area dalam dike. Pada skenario dike 3 memiliki rata - rata tinggi elevasi muka air terendah diantara skenario dike yang lain, hal ini disebabkan oleh skenario dike 3 merupakan dike dengan tipe semi tertutup, yang hanya memiliki satu gap saja.

\section{J. Grafik Cross Section}

Grafik cross section dibuat dengan tujuan untuk menggambarkan proses penjalaran tsunami menuju dike hingga aliran air yang masuk ke dalam dike. Adapun lokasi cross section adalah koordinat UTM Easting 699002.63056 Northing 9330617.0206 (Titik utara), Easting 700364.01085 Northing 9323896.8369 (Titik Selatan) dan diantara titik 
tersebut terdapat 19 titik dengan jarak $220 \mathrm{~m}$ per titik. Lokasi ini dipilih karena terletak pada posisi strategis yaitu center gap. Lokasi tersebut akan digunakan dalam semua skenario dike untuk mengekstrak data. Data yang akan dibandingkan adalah berupa elevasi muka air maksimum pada masing - masing titik.

\section{1) Cross Section pada Skenario Dike 1}

Gambar 17 adalah cross section pada skenario dike 1, yang ditandai dengan simbol A-A', sedangkan Gambar 18 dalaha hasil ekstrak data dari 21 titik pada cross section AA'.

Dari Gambar 18 dapat dilihat bahwa pada titik 1 sampai titik 2 elevasi air masih di atas $1 \mathrm{~m}$, hal ini dikarenakan titik tersebut berada diluar area dike. Pada titik ke 3 elevasi air mengalami penuruanan dikarenakan titik tersebut mulai memasuki area dike. Kemudian titik 4 sampai dengan 21 elevasi muka air sama dengan nol.

\section{2) Cross Section pada Skenario Dike 3}

Gambar 19 cross section pada skenario dike 3, yang ditandai dengan simbol C-C', sedangkan Gambar 20 adalah hasil ekstrak data dari 21 titik pada cross section C-C'.

Dari Gambar 20 titik 1 sampai dengan titik 10 tsunami mengalami penjalaran dengan ketinggian elevasi muka air diatas $1 \mathrm{~m}$. Pada titik 11 (titik pada gap) elevasi muka air mulai mengalami penurunan akibat adanya skenario dike 3, elevasi muka air tersebut adalah $0.6 \mathrm{~m}$. Pada titik - titik selanjutnya elevasi muka air mengalami penurunan dengan nilai elevasi diatas $0.003 \mathrm{~m}$.

\section{3) Cross Section pada Skenario Dike 5}

Gambar 21 cross section pada skenario dike 5, yang ditandai dengan simbol E-E', dan Gambar 22 cross section pada skenario dike 5, yang ditandai dengan simbol E-E'.

Dari Gambar 22 titik 1 sampai dengan titik 9 tsunami mengalami penjalaran dengan ketinggian elevasi muka air diatas $1 \mathrm{~m}$. Pada titik 10 (titik pada gap) elevasi muka air mulai mengalami penurunan akibat adanya skenario dike 5, elevasi muka air tersebut adalah $0.63 \mathrm{~m}$. Pada titik - titik selanjutnya elevasi muka air mengalami penurunan dengan nilai elevasi diatas $0.13 \mathrm{~m}$.

Skenario dike 1 dengan cross section A-A' memiliki rata - rata air terendah setelah melewati dike karena skenario dike 1 adalah tipe dike tertutup. Grafik cross section E-E' memiliki rata - rata air tertinggi setelah melewati dike karena skenario dike 3 adalah tipe dike terbuka dengan gap terbanyak.

Cross section A-A' adalah yang pertama kali mengalami penurunan elevasi muka air, hal ini disebabkan oleh posisi dike yang lebih menjorok ke arah laut yaitu pada titik tinjau 3. Kemudian skenario dike 3 yang posisi gap berada pada titik tinjau 10. Dan yang terakhir skenario dike 2 yang posisi gap berada pada titik tinjau 11 .

\section{K. Persentase Penurunan Elevasi Muka Air}

Nilai persentase bertujuan untuk menggambarkan penurunan elevasi muka air yang terjadi setelah adanya dike. Nilai persentase merupakan perbandingan dari elevasi muka air sebelum adanya dike dan setelah adanya dike. Nilai elevasi muka air yang dibandingkan merupakan hasil ekstrak data pada titik - titik tinjau yang berada pada area dike, sehingga rata - rata penurunan elevasi muka air dapat ditentukan. Perhitungan persentase dilakukan pada masing masing skenario Dike. Hasil persentase penuruan elevasi muka air dapat dilihat pada Tabel 4.

\section{KESIMPULAN}

Tsunami akibat erupsi Gunung Anak Krakatau dapat dimodelkan dengan bantuan software MIKE 21 modul hydrodynamic pada Flow Model FM. Adapun kondisi kenaikan muka air pada pemodelan merujuk pada tsunami akibat erupsi Gunung Krakatau 1883. Dari hasil pemodelan penjalaran tsunami yang telah dilakukan, hasilnya tidak jauh berbeda dengan data validasi. Validasi hasil pemodelan dapat dilihat dari hasil running pada titik tinjau yaitu Easting 701091.346171525 dan Northing 9325432.75281731 (dalam koordinat UTM), yang lokasinya berdekatan dengan Pelabuhan Mutiara di Teluk Jakarta. Berdasarkan hasil analisis pemodelan diperoleh ketinggian elevasi muka air $1.437 \mathrm{~m}$ sedangkan tinggi elevasi muka air dari data validasi adalah $1.451 \mathrm{~m}$.

Pemodelan tsunami dike dengan beberapa skenario adalah sebagai upaya untuk mengurangi ketinggian gelombang tsunami yang sampai di Teluk Jakarta. Adapun skenario dike yang dimodelkan terdiri dari 3 tipe, diantaranya adalah base case dengan tipe tanggul tertutup, tipe tanggul terbuka dengan 7 gap, tipe tanggul semi terbuka dengan 1 gap, tipe tanggul yang mempertimbangkan rencana reklamasi dengan 5 gap, dan tipe tanggul terbuka dengan 11 gap. Pemodelan dengan skenario dike dapat mengurangi tinggi elevasi muka air di dalam area dike masing - masing adalah $100 \%$ untuk skenario dike 1 (tipe dike tertutup), $99.58 \%$ untuk skenario dike 2 (tipe dike semi tertutup dengan 1 gap), 86.26\% untuk skenario dike 3 (tipe dike terbuka dengan 11 gap).

\section{UCAPAN TERIMA KASIH}

Terima kasih kepada Kepala Balai Penelitian dan Pengembangan Pantai yang telah memberikan izin penggunaan software MIKE 21 dan semua pihak yang telah membantu dalam penelitian ini.

\section{DAFTAR PUSTAKA}

[1] E. Tantri, "Letusan Krakatau 1880: Pengaruhnya terhadap gerakan sosial Banten 1888," J. Masy. dan Budaya, vol. 16, no. 1, pp. 191214,2014

[2] D. Suhadi, A. Karim, A. Dahlan, I. Ridwan, and T. Rukada, Inventarisasi Topografi Gunungapi Anak Krakatau. Bandung, Indonesia: Pusat Vulkanologi dan Mitigasi Bencana Geologi, 2004.

[3] B. Triatmodjo, Teknik Pantai. Yogyakarta: Beta Offset, 2016.

[4] R. W. Mahardika, A. Ismanto, and P. Purwanto, "Studi perbandingan simulasi flow model FM dan ADCIRC terhadap pola arus pasut perairan Teluk Lembar Lombok," J. Oceanogr., vol. 4, no. 1, pp. 206-214, 2015. 